\title{
A Boost-Up Mechanism For High Performance E- Governance in Bangladesh
}

\author{
Nazmus Sakib \\ Islamic University of \\ Technology (IUT)
}

\author{
Paramita Basak Upama \\ Bangladesh University of \\ Engineering and Technology
}

\author{
Humaira Tasnim Proma \\ American International \\ University Bangladesh (AIUB)
}

(BUET)

\begin{abstract}
A classic chapter of "E" prefix concept, E-governance is the buzz content. Developed countries have already implemented the idea of automation system for their fundamental institution which are related and accessed for the basic needs. Automation process has changed the life of the citizens in an enhanced way, so that people can stay relax on their desired services and give the input more precisely in the production environment. The citizens get all service in an centralized way, get more involved with the development schemes of government and helps to improve their living and social aspects. But in developing countries like Bangladesh, Egovernance presents only in few sectors though there's different challenges of Power, Connectivity and Information Technology Knowledge. Moreover, huge hurdles in total implementation of the scheme, Bangladesh still has some scope to boost up existing E-governance system by following a different path which may not look like conventional. The areas of concentration of these scopes are much familiar, but have always been neglected, so that if the proper mechanism can be used on those unused sector that can give more potential outputs. This paper tries to formulate the different mechanics of implementing E-governance which shows Bangladesh high prosperity.
\end{abstract}

\section{Keywords}

E-Government, E-Governance, Developing Country, Digital Bangladesh, Government Automation, Information Communication Technology, Employment Policy

\section{INTRODUCTION}

E-government is a method of governing the citizens in a digital way which is basically the Electronic Government [1]. Egovernance is defined as the application of Information and Communication Technology (ICT) for delivering government services, exchange of information, integration of service systems between government-to-citizen, government-tobusiness and government-to-government [2] [3]. Though this method improvises government services but the main focus to create the effect of connectivity and reliability to the citizens in a convenient, efficient and transparent manner [4] [5]. Types of E-government can be classified into eight groups [6]. These classifications are mostly vice versa ,here are these i) Government-to-Citizen (G2C), ii) Citizen-to-Government (C2G), iii) Government-to-Business (G2B) , iv) Business-toGovernment (B2G), v) Government-to-Employee (G2E), vi) Government-to-Government (G2G) , vii) Government-toNonprofit (G2N) and viii) Nonprofit-to-Government(N2G).

These all classifications are bind in a frame to facilitate the people and make integration among the social and financial services of the public and private organizations [7]. The vision of the E-governance is too extend that all the aspects of the government like giving a One-stop Medical Service to
Enabling pension scheme is making convenient to the citizen that can create a huge change and motivation on positive speed of development [8]. It definitely enhances the monetary value of the services in a dignity position which is already achieved by the organizations of European and North American countries [9] [10]. The functionality will be implied on its best when core is supplying the information which are integrated for developing concerns [11]. If we open the envelope of this context we can find out this sort of diagram (fig: 01) in below:

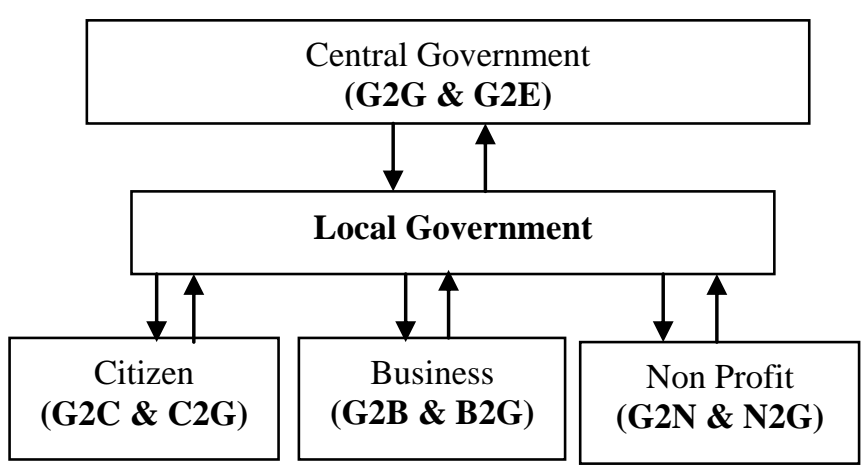

Fig: 01

The diagram shows four types of activities among domains of these platforms [12]. Firstly, Spreading information of the services, like-regulatory services, general holidays, public hearing schedules, issue briefs, notifications, etc. over the Internet. Secondly, Two-way digital communications between the agency and the citizen, a business, or another government agency. Thirdly, Conducting transactions, such as-lodging tax returns, applying for services and grants etc. and finally, Governing the citizens, such as- to enable the citizen to transit from passive information access to active citizen participation by some specific ways like: i) Informing the citizen, ii) Representing the citizen, iii) Encouraging the citizen to vote, iv) Consulting the citizen and v) Involving the citizen.

A nation's GDP per capita compared to other nations is a major reference of its being a developed or developing country. A developing country, Bangladesh which is still treated as a third world country is starting to evolve to add a prefix "E" in service aspects [13]. This nation with a less developed industrial base, and a low Human Development Index captive to initialize the vision of Digital Bangladesh 2021 in all the departments of the Government [14]. Implementation of Egovernance have some basic requirements, for example proper infrastructure and equipment of Internet services. Bangladesh current having six mobile operators and Govt. already ensured Internet services to every Union Parishad Centers. The National ID Card program creating a huge database for transparency of information and service. For smart government policy the data and the information should be convenient access of service and providing service to each and every 
corner of the country [15]. As developing countries the scheme design of the government is mostly biased by the political affiance, but the modernization of the government through Egovernance should keeping service schemes beyond political differences [16].

The rest of the paper is organized as follows. In section 2, we describe the brief overview of related study on e-services which will support the platform of E-governance. In section 3, we analysis the specific sectors for boost up policy issue of enabling e-governance. Then section 4, necessary steps of implementing E-Governance. Finally, Section 5 concludes.

\section{RELATED STUDY}

Implementation of E-governance in Bangladesh is much challenging as the needs of service are always increasing and requirements are harder to fulfill because feasibility is not in the standard package for the citizens [17] [18]. Lack of proper knowledge of computer and Internet services among citizens, less or no access of computer and Internet service in most rural areas and insufficient funding in implementation of proper infrastructure needed to provide countrywide service could be main issues that hinder the proper implementation of E-governance in Bangladesh [19] [20]. Moreover, No automation of the government agencies, Central Data Migration and Lack of public awareness about government services and regulation can create hassle in getting required service though the e-portals [21]

The most important requirement which can play the vital role of providing E-governance service is Internet connection [22] [23]. This area needs much more concentration if the government wants to properly provide online service. But the good news is that the internet penetration is increasing day by day. Moreover, broadband internet through local ISP is popular all over the country. Besides, people are using mobile internet services for data usages and application usages [24]. A Graph (Fig. 02) below showing the increment of consumers on the Data Centric penetration for last one year in Bangladesh.

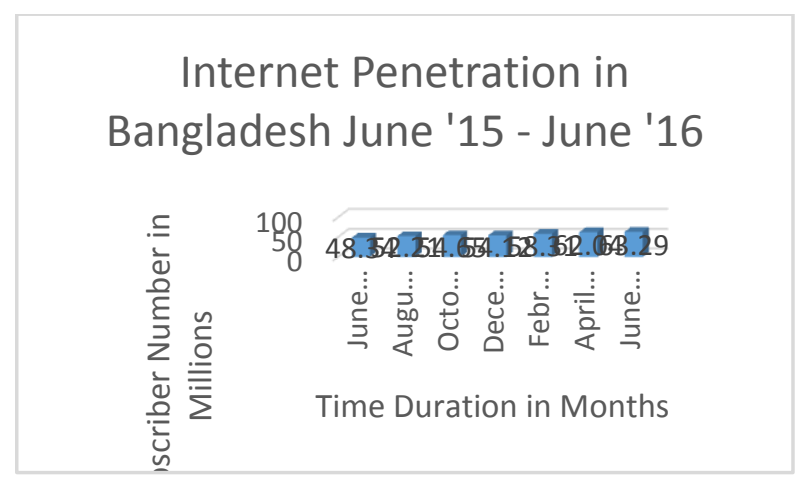

Fig. 02

According to the above graph, only $25 \%$ of the total population used the Internet in 2015s. By 2016 the number of Internet users in Bangladesh had seen phenomenal growth and $36 \%$ of total population started using Internet. It became possible mainly due to wide availability of mobile Internet access, as fixed line penetration rates are higher than that of mobile Internet connections [25] [26] [27].

Some other issues are raising which horn like lack of knowledge of computer and Internet, even of English language whereas, Most of the E-government portals, or at least some parts of it, are written in English. The rural people, who are deprived of primary education, are unable to understand English. As a result, they do not understand what the E-portals say, and are unwilling to use the portals. Thus, people who are able to understand English portals, are deprived of basic knowledge regarding computer and Internet. So it becomes impossible to them to use the portals, even if they have Internet connections available. Approximately 50\% of the citizens are in this group [28]. Due to lack of primary education as well as trainers of computer and Internet in the remote areas of the country, the E-government scheme loses its importance.

Here, there are a lots of opportunity though we are in the back footed position, but the proper maintenance and enhanced policy that can create huge opportunities for boosting us the performance of the E-Governance in Bangladesh. Moreover, three points mention in below which definitely reflects the idea of boosting up and opportunity to find out a beautiful future for Bangladesh.

\section{A. Selecting the central authority to manage $E$ - governance:}

Each government ministry and division has its own rules and ways of work. Moreover, the non-governmental bodies differ in their work way too much from governmental bodies. All of them cannot be easily arranged under one single authority. The authority should be capable enough to manage different bodies of different formats, and work as a central management entity in the system [29] [9]. In the scenario of Bangladesh, a ministry or division will not be able to collaborate with other government and non-government bodies. So the office of the Prime Minister, who is responsible for management of all government bodies, can run and manage E-governance easily.

\section{B. Providing Internet connection throughout the country:}

Internet connection is one of the basic needs to implement Egovernance system [30]. In Bangladesh, there are broadband connections from government run organizations in every district. But their speed is low and cost is too high [25] [26]. So government as well as non-government organizations can take up the responsibility to set up high speed and low cost Internet service providing system. In this case, they can use small Wi-Fi routers to spread connections in every remote area. The Wi-Fi routers will provide low cost and high speed Internet connection using mobile phone networks, as even each remote area is now under mobile phone network [25].

\section{Connecting people to the E-governance system:}

Today, people over 18 years of age have been provided a National Identification Card. The number of this card (NID) is helpful to easily identify a person. NID can be used to access different portals of E-governance system. Also, to avail service from these portals NID can be used. Basic training of computer and Internet will be helpful to the people. Those availing service from E-governance portals will pay a minimal fee to the service provider. This, in turn, will help the service providers to provide more and better service.

\section{BOOST-UP SECTORS ON E- GOVERNANCE}

\section{A Basic Need : Health Care Service}

Along with primary health care advice, total health care service is becoming a necessity in Bangladesh. As the best medical facilities and doctors are available in big cities only, it becomes impossible to rural people to access them. We cab pledge here an example, with the help of online health service, people living anywhere in Bangladesh will be able to get live consultation from any doctor living anywhere. The rural hospitals or health centers will also be able to contact the big 
hospitals live whenever needed. As nation is connected now through mobile phone network and internet so, village people can easily get access to the high level professionals within a second and payment can be done through some mobile financial services.

\section{E. Job in home ( In house career) : Content Writing}

Content or matter writing for websites or webpages are very popular in job sector. Unemployed people can join this job, which will be helpful to both these people and the companies for which they work. Example: An unemployed boy or girl, spending lots of time in social networks, can be appointed to write some content while being online by a company.

\section{F. Distance Learning :Online Education}

Online education system is useful for a student to learn anything from anywhere in the country, at free of cost or little cost. It will meet the need of good teachers, proper books and other study materials in remote areas of the country. Such that the unemployed educated people can join the creators of such portals, make lesson plans and upload lectures here. They will get payment on the basis of their work.

\section{G. Enhanced Selling: Product from Field to Factory}

Online buying and selling system without involvement of any middle man can be the idea. Using the online portals of different government ministry or division, the rural people can sell their own products directly to the authoritative person. This process will remove the middle men from the buying and selling cycle. It is useful for farmers, small business persons, entrepreneurs etc. living in remote and rural areas of Bangladesh. Here is suitable scene may be like that, A group of farmers, living in a remote and rural area, grows jute in fields. When the fibers are ready to sell the farmers will contact the respective ministry through their website. The authoritative person from that ministry will in turn contact the farmers and collect fibers from them and group of the productive farmers will receive payment through bank account.

\section{H. Supporting E-commerce: Online Market}

Online shops of various products will bring the world closer to any citizen living in any corner of the country. Going to big cities to buy commodities will no longer be needed. A village school needs to buy some computer for the students. The authority can place their order to any big shop in any city through the website of that shop, without visiting that shop. The payment will be cleared after the products reach the school.

\section{Security: An alarming Issue for Society}

The government is taking adequate security measures for the betterment of citizens. But only a few government employees are involved in this job. If the general people are also given some responsibility of this job, the work will be done smoothly as well as people will be benefitted. Suppose, an unemployed boy or girl is given responsibility to monitor activities captured by 5 surveillance cameras, and report any anomalous or unusual activity. He or she will be able to inform the police station, fire station, ambulance service or technical management team using a web portal whenever such activity is monitored. That person will be paid for this work. This will create huge job for the uneducated person cause watching a camera and inform through some button of a device is not a great deal. It positively encourage people for different jobs dimensions and also decrease the unemployed scenario.
According to figure-03 (a scenario of a proposed online surveillance system), when the person in charge of monitoring the activities captured by the surveillance camera finds something unusual activity, he or she will inform the respective authority via the web portal to handle the situation.

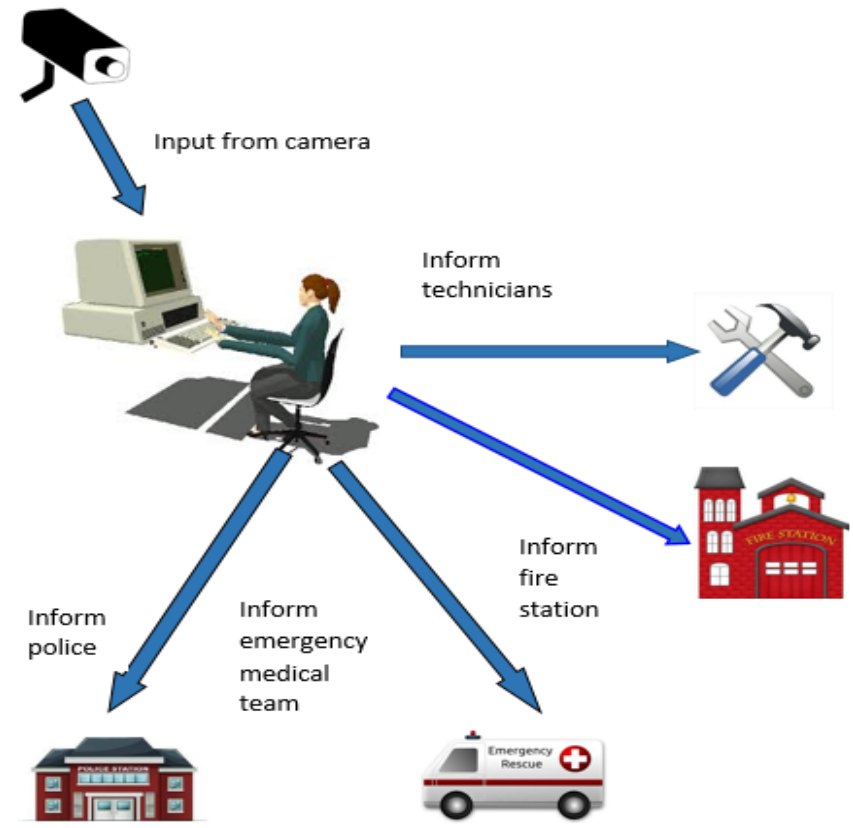

Fig: 03

When an accident occurs, the nearby police station and emergency medical team will get signal through web portal. In case of fire, nearby fire station will get the information through web portal. If a car breaks down in the spot under surveillance, technicians will be informed for emergency help through the web portal. The technicians will also be able to help if the surveillance camera faces any trouble while working. Similar system is possible for each and every service, provided by government and non-government organizations in Bangladesh, that have been described above.

\section{J. Tourism: An Aspect to Show Beautiful Bangladesh}

Tourism is one of the prospective opportunities in Bangladesh. The government run tourism department cannot alone set up a database of tourist spots throughout the country. They can involve local people of different spots as well as tourists in this work. A person living or visiting a tourist spot has enough useful information about the spot. He or she can share the photos, routes to be taken to reach there, arrangement of food and lodging, best time to visit there, tourist attractions about the spot on the web portal of tourism department. The department will pay the person for sharing the authentic information or it might be no-profitable work for any social organization too. Thus new visitors will be helped.

\section{K. DataCentric Project Management}

Online database of school/college/university project groups: Students of any ages from different educational institutions can be connected to each other through this type of database. They can share their own projects, or even project ideas in it. It will be connected to different governmental and nongovernmental organizations who are interested in funding and buying projects from young innovators. Example: A team of university students make a solar energy driven car. They get small or no funding from the university. If a Car Company/ solar power company is interested in such projects, they can contact that team through the database. They will sponsor the 
team to advance the project, take part in different competitions at national and/ or international level, or make them work with the organization.

\section{PROPOSED STEPS OF IMPLEMENTING E-GOVERNANCE}

There are huge scope of development in the arena of education, health, Mobile Financial Services (MFS), transportation services can rapidly convergence of specialized services. The Vertical disintegration has created immense potential for the service industry of Bangladesh to benefit of specialization of new service products. Young people of different ages will get work according to their qualification. Thus unemployment will be eradicated gradually.

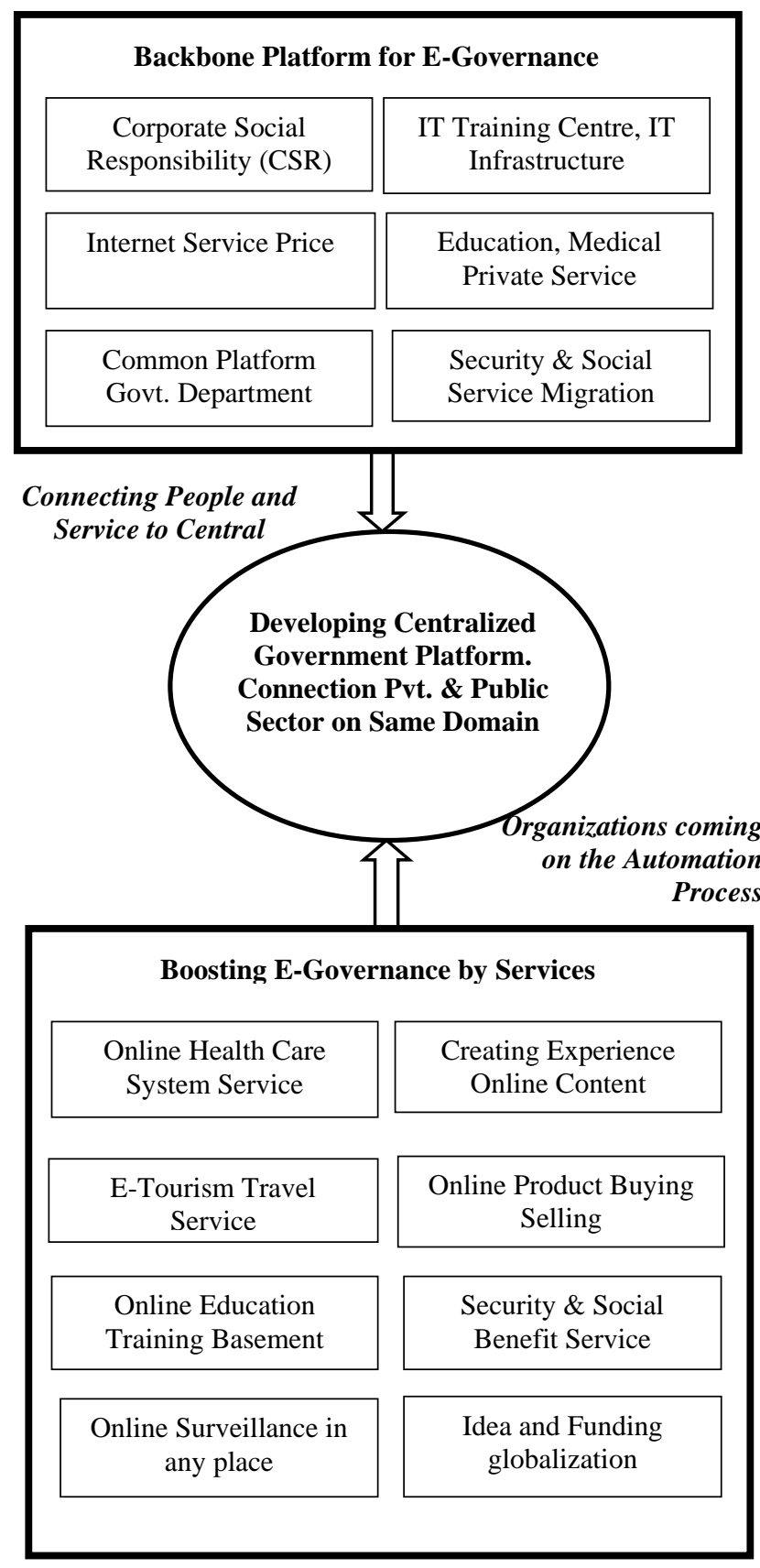

Fig: 04

Young innovators will be benefitted by getting different help from different organizations of the country, when they are connected to these organizations through various online portals.

Even, Small business person or entrepreneurs will be benefited by selling their products directly to the buyers, without facing any trouble from any middle man. Online education system will remove all barriers that stop students of remote areas from acquiring knowledge. Online shops will make shopping easier for village people, who need to go to city for each and every purpose at current time. Online surveillance system will be helpful in providing more safety to citizens, as well as providing jobs to them in various sectors of the system. Thus in E-governance system, governance will be systematic and people will get service in an easier way.

With the growth of mobile technology, data service and smart phone usage, as opportunity is evolving to offer diverse services over such technology network. For the backbone of the E-governance Internet service should be ensured because all of the services are connected through cloud and diversified though out the Mobile or Broadband internet.

Hence, specialized service provider uses different channel to distinct their service policy and optimize the core competence. Service providers and the Outsource personnel or organization will be connected with the same channel and provide the service as central. Suppose, a central network is provided for the health care service, old care service and insurance platforms. Now, if an old woman feeling sick she can be survilenced by any person through some camera or devices which is managed by old care services. As old care services is connected with the central they can take help from the health management system even, they can take financial decision of any medical emergency if they know the insurance policy of that old woman. We have shown some of the services which can be integrated in the system though the channel of Government. As Bangladesh Government now very much interested in enabling the digitalization so e-governance will be a sustainable and profitable mechanism to endure a revolution in the service industry.

\section{CONCLUSION}

The ideas proposed here have been discussed considering the current scenario of Bangladesh. There could be many other issues which need to be implemented to derive the benefits of the E-governance cause this aspect will directly tune the insights and outsights of the social, economic, cultural and political domains. It will be really hard to interpret the wholesome effect of the automation, and also critical of showing of evidences within sound theoretical framework. If Bangladesh wants to develop more and make progress then adapting better E-governance scheme is a mandatory. The proposed ideas truly realistic, as they have already been implemented in some countries around the world. They will make the existing E-governance scheme much better, attract more citizen to receive E-services and improve their living. By using this types of mechanism, convergence from manual concept to the digitization of the technology and adopting the service oriented business, meet the demand of the customer service under controlling by Government of Bangladesh.

\section{REFERENCES}

[1] F. Bannister and R. Connolly, "Defining e-Governance," e-Service Journal, vol. 8, no. 2, pp. 3-25, 2012.

[2] P. Rossel and M. Finger, "Conceptualizing eGovernance," in 1st International conference on Theory and practice of electronic governance, 2007. 
[3] M. Finger and G. Pécoud, "From e-Government to eGovernance? Towards a Model of e-Governance," in Proceedings of the 3rd European Conference on EGovernment-ECEG, 2003.

[4] D. D. Potnis, "Measuring e-Governance as an innovation in the public sector," Government Information Quarterly, vol. 27 , no. 1 , pp. 41-48, 2010.

[5] S. Myeong , Y. Kwon and H. Seo, "Sustainable EGovernance: The Relationship among Trust, Digital Divide, and E-Government," Sustainability, vol. 6, no. 9, 2014.

[6] Z. Fang, "E-Government in Digital Era: Concept, Practice,and Development," Iternational Journal of The Computer, The Internet and Management, vol. 10, no. 2, pp. 1-22, 2002

[7] T. Nam and T. A. Pardo, "Conceptualizing smart city with dimensions of technology, people, and institutions," in Proceedings of the 12th Annual International Digital Government Research Conference: Digital Government Innovation in Challenging Times, 2011.

[8] T. Zwahr and M. Finger, "Critical steps towards eGovernance: a case study analysis," in European Conference on Electronic Government, Vienne, Autriche, 2004.

[9] K. Paskaleva, "Assessing Local Readiness for City EGovernance in Europe," International Journal of Electronic Government Research, vol. 4, no. 4, pp. 17-36, 2008.

[10] B. A. Allen, L. Juillet, G. Paquet and J. Roy, "EGovernance \& government on-line in Canada: Partnerships, people \& prospects," Government Information Quarterly, vol. 18, no. 2, pp. 93-104, 2001.

[11] N. A. Siddiquee, "E-Government and Innovations in Service Delivery: The Malaysian Experience," International Journal of Public Administration, vol. 31, no. 7, pp. 797-815, 2008.

[12] S. C. J. Palvia and S. S. Sharma, "E-Government and EGovernance:Definitions/Domain Framework and Status around the World," in E-governance Foundation, ICEG, 2007.

[13] M. Backus, "E-Governance and Developing Countries: Introduction and examples," 2001.

[14] A. Sullivan and S. Sheffrin, Economics: Principles in action, New Jersey: Pearson Prentice Hall, 2003.

[15] X. Zhou, "E-Government in China: A Content Analysis of National and Provincial Web Sites," Journal of Computer-Mediated Communication, vol. 9, no. 4, 2004.

[16] C.-W. Tan, S. L. Pan and E. T. Lim, "Managing Stakeholder Interests in e-Government Implementation: Lessons Learned from a Singapore e-Government Project," Journal of Global Information Management (JGIM), vol. 13, no. 1, 2005.

[17] T. Obi, "Current topics in the discussion on the relationship between e-governance and education," in
Proceedings of the 2nd international conference on Theory and practice of electronic governance, 2008

[18] P. Sharma, A. Mishra and P. Mishara, "E-Governance in India is the Effectual and Challenging Approach to Governance," International Journal of Business Management \& Economic Research, vol. 2, no. 5, pp. 297-304, 2011.

[19] M. J. Alam, "E-Governance in Bangladesh: Present Problems and Possible Suggestions for Future Development," International Journal of Applied Information Systems (IJAIS), vol. 4, no. 8, pp. 21-25, 2012.

[20] M. R. Hassan, "E-Governance and E-Government in Bangladesh:Performance,Challenges and Remedies," Asian Journal of Applied Sciences and Engineering, vol. 2, no. 2, pp. 111-117, 2013.

[21] S. S. Dawes, "Advancing e-governance: connecting learning and action," in Proceedings of the $1 \mathrm{st}$ international conference on Theory and practice of electronic governance, 2007.

[22] J. C. Bertot, P. T. Jaeger and J. M. Grimes, "Using ICTs to create a culture of transparency: E-government and social media as openness and anti-corruption tools for societies," Government Information Quarterly, vol. 27, no. 3, pp. 264-271, 2010.

[23] T. M. Waema and W. Mitullah, "E-governance and governance: a case study of the assessment of the effects of integrated financial management system on good governance in two municipal councils in Kenya," in ACM, 2007.

[24] "Internet users (per 100 people) | Data | Table," [Online]. Available: http://data.worldbank.org/indicator/IT.NET.USER.P2/co untries/.

[25] N. Sakib, J. T. Khan and P. B. Upama, "Smart Use and Sustainable Architecture of Wi-Fi in a Metropolitan City: Dhaka," International Journal of Computer Applications (IJCA), vol. 132, no. 2, pp. 19-23, 2015.

[26] I. Islam, Bangladeesh Telecoms Sector Challenges \& Opportunities, AT Capital Research, 2010.

[27] "GDP per capita (current US\$) | Data | Table," [Online]. Available: http://data.worldbank.org/indicator/NY.GDP.PCAP.CD.

[28] "Internet World Stats," [Online]. Available: http://www.internetworldstats.com/asia/bd.htm.

[29] T. A. Pardo, T. Nam and G. B. Burke, "E-Government Interoperability:Interaction of Policy, Management, and Technology Dimensions," Social Science Computer Review, vol. 30, no. 1, pp. 7-23, 2012.

[30] B. A. Amaba, "Industrial and Business Systems for Smart Cities," in Proceedings of the 1st International Workshop on Emerging Multimedia Applications and Services for Smart Cities, 2014 